\title{
Long-Term Trends and Policy Challenges in Chilean Agricultural Labor Markets
}

\author{
Gustavo Anríquez \\ Pontificia Universidad Católica de Chile, Santiago, Chile.
}

\begin{abstract}
G. Anríquez. 2021. Long-Term Trends and Policy Challenges in Chilean Agricultural Labor Markets. Int. J. Agric. Nat. Resour. 210-232. This paper identifies the major longterm trends in agricultural labor markets in Chile. The document shows the increasing aging, feminization, and seasonality of the agricultural labor force. Long-term projections are made regarding the evolution of labor supply and demand based on demographic and economic trends. These projections suggest the continuation of the already existing trends of a decreasing supply of labor and an increasing demand for agricultural labor, mostly driven by the substitution of crops into labor-intensive but higher-value export crops. Hence, the paper predicts a continuation of the trend of rapidly increasing labor costs in agriculture. The paper discusses the challenges imposed on farmers and policy-makers of confronting these rapidly growing labor costs by continually raising farm labor productivity.
\end{abstract}

JEL Codes: J43, Q13, Q18

Keywords: Agricultural labor, Chile, factor markets.

\section{Introduction}

There are growing complaints among farm lobby groups that the country is suffering from an alleged "shortage" of labor in agriculture that would threaten the development of the sector. These complaints should be understood more as complaints about the rapid rise in labor costs in agriculture rather than as a lack of people physically. However, the challenges posed by these continuous increases in employment costs for the industry are real, and they are growing, as we demonstrate here. Agriculture is paying the costs of its own success: its constant expansion and, in particular, the expansion of higher-value but more labor-intensive crops are inevitably taking their toll in the form of an increasingly "tight" agricultural labor market. Additionally, there is growing competition from a growing urban sector that is more integrated with rural markets, which means that the "shortage" of labor that farmers perceive is a growing challenge. On the other hand, agriculture in Chile, as in most of the world, provides the main economic support in

Received Apr 24, 2021. Accepted Nov 16, 2021 
rural areas and is closely linked to the well-being of the poorest in the country.

This paper aims to help in the design of policy actions that aid in tackling these challenges in the medium and long term. First, the document describes major long-term trends observed to date in agricultural labor markets. Then, the main socioeconomic and demographic processes that explain these trends are identified, focusing on those that can be used to make long-term projections in these markets. The individual and market responses to the growing challenges presented by the agricultural labor market are then identified. Then, this study describes the evolution of the well-being of agricultural wage earners, one of the most vulnerable social groups in Chile. Additionally, predictions are made regarding the future evolution of the well-being of agricultural laborers, based on an analysis of the evolution of the agricultural labor markets. Finally, the role of the public sector in supporting the agricultural sector to face these growing challenges in terms of labor costs is discussed.

\section{Long-term Transformations of the Agricultural Workforce. Trends and Predictions}

Employment time series have existed in Chile since the mid-1980s. These statistics show a somewhat surprising evolution. While the contribution of agriculture to the national GDP (value added) has fallen by practically $60 \%$, from $7.4 \%$ to $3.2 \%$ of GDP, the number of employees in agriculture has remained relatively constant during these last three decades, at approximately 800 thousand workers. Although the overall number of employees in agriculture has remained relatively stable, under the stability of this global indicator during this long period, there are important changes in the composition of this labor force that we highlight in this section.

The evolution of employment in agriculture for the period 1985-2019 can be seen in Figure 1, together with the seasonally adjusted trend. The graph clearly shows how agricultural employment has a strong seasonal component, with demand peaks between December and March and minimum demand around June and August. Over this extended period, employment tended to rise until the return to democracy (1989) and to decline during the 1990s. At the end of the last century and after the Asian crisis, employment in agriculture rose again. These trends show that agricultural employment is partly anticyclical, as argued in (Anríquez et al., 2005), showing an increase (more clearly seen in the seasonally adjusted series) during periods of economic decline.

The figure also includes the evolution of employment in construction. Construction sector employment presents a clear contrast to agricultural employment, since it is not seasonal and is strongly procyclical. Construction employment has been increasing together with the growth of the overall economy. It is important to contrast employment in the construction sector because it is the other major employer of unskilled labor, and that sector growth means growing competition for agriculture as they contend for the same human resources (both sectors have the workforce of permanent employees with the lowest average education levels, according to all 21st century national household surveys - CASEN). This competition is becoming stronger, not only because of the growth in demand for labor in the construction sector, but also because the improvements in communications, transportation, and increased purchasing power brought about by the country's development facilitate workers' permanent and transitory migration between sectors. As shown in (Winters et al., 2008), the construction sector is one of the main employers in rural areas of developing countries, but in Chile, this intersectoral competition is amplified by the greater integration of urban and rural labor markets. There is additional recent evidence that highlights this interaction between agricultural and construction labor markets. The first representative survey of seasonal agricultural employment 


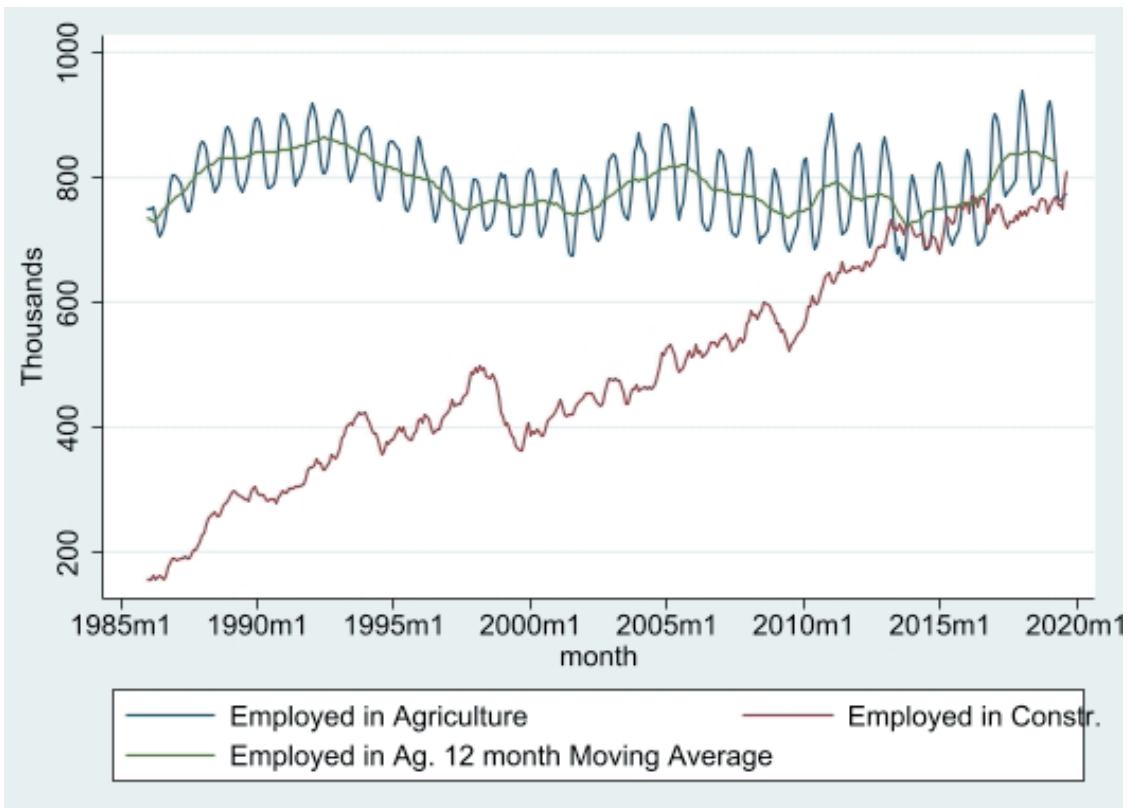

Figure 1. Evolution of Employment in Agriculture and Construction, Chile 1985-2019.

Source: INE national employment surveys.

presented in (Anríquez et al., 2016) shows that one in five seasonal employees in agriculture worked in sectors other than agriculture, and among them, one in four was employed in the construction sector. Consistent with this growing competition between sectors and the greater integration of labor markets is the closing of the gap between the sectors' wages: if in 2000 a seasonal agricultural employee earned $55 \%$ of what a construction worker earned, by 2009 a seasonal agricultural employee earned almost 70\% (Anríquez et al., 2016).

The first salient feature of agricultural employment is its increasing seasonality, in other words, its increasing dependence on "seasonal workers." Identifying a seasonal worker in agriculture in statistics is not easy. This is why two definitions are proposed here: the legal, or de jure, definition identifies workers in agriculture who have short-term contracts (less than three months) or contracts by job completed. This is a valid definition of a temporary employee; however, many de jure workers can keep working in the sector for most of the year, signing various short-term contracts with breaks on the same site or different sites. This leads us to a second definition of seasonal workers, those de facto, i.e., the worker who in practice works in the sector only during the season of greatest demand. De facto seasonal workers can be identified as the difference between the maximum and minimum demand for employment in the sector during a calendar year. It is estimated that de jure seasonal workers are between 300 thousand and 350 thousand. This number is higher than that of de facto temporary workers, since many of those with short-term contracts continue to be employed in the sector during the year. Figure 2 shows the evolution of de facto seasonal workers, who currently amount to 200 thousand employees. The figure also clearly shows the upward trend of this seasonal employment. Finally, as the number of employees in the sector has remained relatively constant, this means that the proportion of total employment in agriculture that is seasonal has been increasing.

Another important characteristic of the agricultural labor force is its increasing feminization, understood in this document as an increase in the 


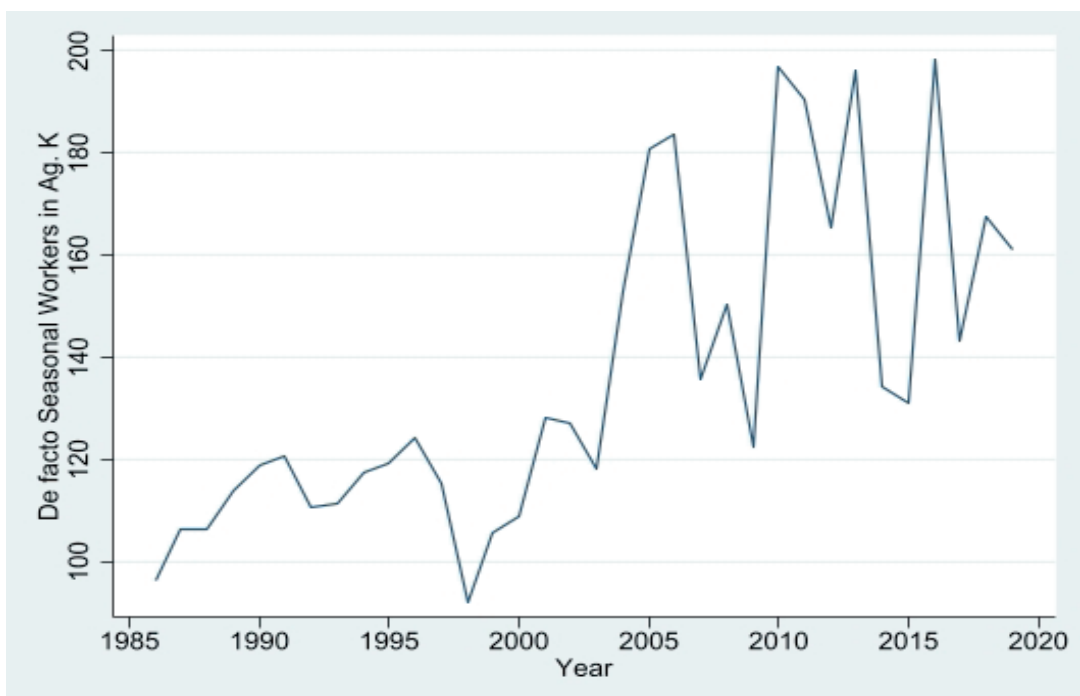

Figure 2. Evolution of De Facto Seasonal Workers in Agriculture.

Source: INE employment surveys.

relative participation of women in employment. The increase in wages during these last decades has caused a significant increase in the opportunity cost of women's time. This phenomenon associated with the country's development has been accompanied by a growing participation of women in the labor force and a significant drop in fertility rates, as is normally observed in more developed countries. In 1986, women represented slightly less than $30 \%$ of the labor force in Chile; today, they represent more than $41 \%$ (INE, 2021). However, this increase in the participation of women in the labor market has not been the same across sectors. Figure 3 shows how the participation of women in the agricultural workforce has increased more than female employment in the construction sector workforce. In both sectors, the increase in female participation is noticeable, as the figure shows; however, clearly, the increase in female participation is more noticeable in the agricultural sector. Furthermore, women are the main contributors to seasonal employment in agriculture, and gender differences are overwhelming in this regard (see also, Jarvis \& Vera-Toscano, (2004)). While less than $20 \%$ of male employment is de facto seasonal, approximately $70 \%$ of female employment in agriculture is de facto seasonal.
In other words, women play an increasingly crucial role in meeting the demand for agricultural employment during the critical summer period, when demand reaches its seasonal highs.

These significant transformations in rural labor markets would have impacts on rural households' welfare and social relations. For example, the prevalence of female-headed households (FHH) grew over the period, from $16.4 \%$ to $32.8 \%$ from 1990 to 2017. Additionally, the per capita income gap between FHH and male-headed households, which in rural areas in Chile favors FHH, was reduced from $54 \%$ to $10 \%$. These changes suggest a reduction in de facto $\mathrm{FHH}$ and a rise in the prevalence of de jure $\mathrm{FHH}$, changes that the empowerment of employed females would allow. These considerable social changes brought about by the feminization of agricultural employment need to be further studied.

Another important trend in the agricultural workforce is aging. Chile's workforce is aging as a result of its demographic transition. The fertility rate has fallen, and the new age cohorts entering the labor force are smaller than previous cohorts. If in 1990 the employees were 


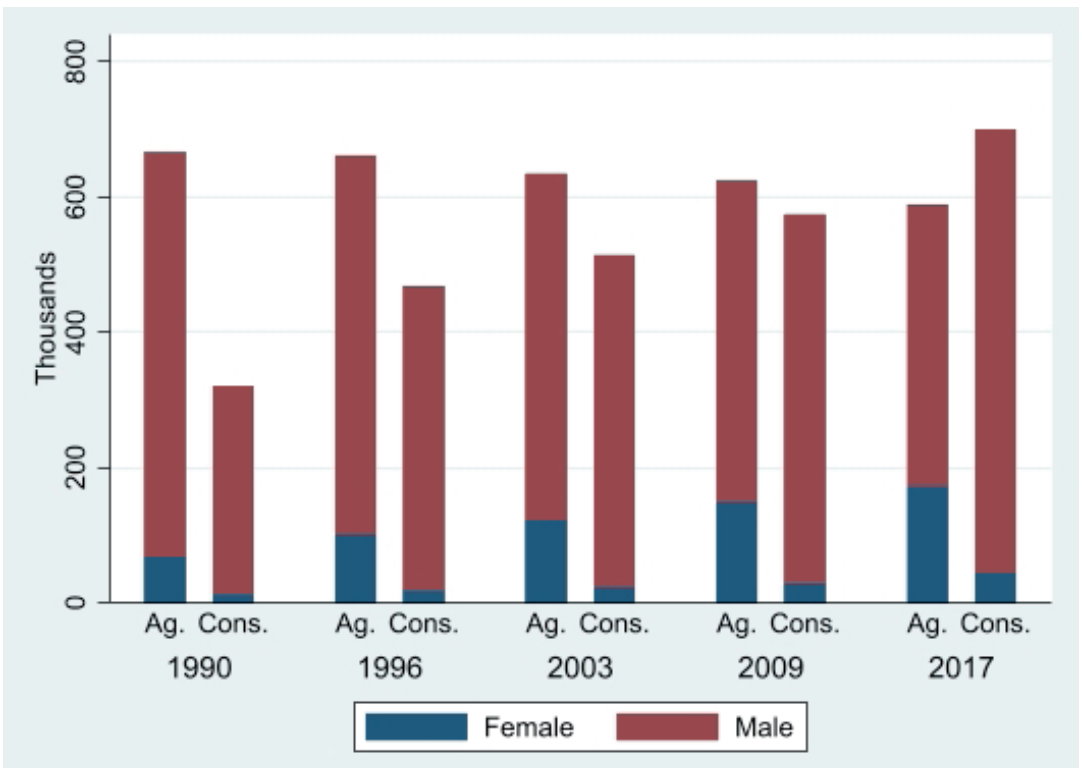

Figure 3. Evolution of Employment in Agriculture and Construction by Gender.

Source: CASEN household surveys from various years.

36.6 years old on average, by 2015 they had an average age of 42.1 years, that is, a $15 \%$ increase in the average age of the employees. However, aging has been even more accelerated among those employed in agriculture. The average age of employees in the sector rose by $23 \%$, from 36.4 to 44.8 years on average. This aging, together with the feminization of employment, can be seen in the collection of demographic pyramids separated every six years, as shown in Figure 4. Aging is graphically described in these demographic pyramids as a transition from a pyramid itself to a cylinder and then to an inverted pyramid. In addition to aging, the figure shows how the sector attracts fewer men to the workforce, and if it were not for increasing female participation, employment in agriculture would have fallen. The rapid aging of the agricultural labor force needs to be more carefully explained, but there are two likely suspects for this increasing trend: the lag in the reduction of the total fertility rate of rural areas vis-à-vis urban areas brought about by rural development and the migration of better educated younger generations who can receive better returns to human capital accumulation in urban areas.

\section{Agricultural Employment Supply and Demand Projections}

In a recent study on seasonal employment in agriculture (Anríquez et al., 2016), the authors presented projections of future demand and supply of seasonal employment for a five-year term. In this section, we use the conceptual model of these authors to discuss the main determinants of the future demand and supply of employment in agriculture and analyze whether we can make projections regarding agricultural labor supply and demand based on expected trends brought about by the development of the country and the sector.

The demand for labor can be traced transparently to the employment requirements of the different crops for a given area. For a given crop (i), the demand for employment $L_{i}$ would be:

$L_{i}=H_{i} \cdot A_{i}$ 


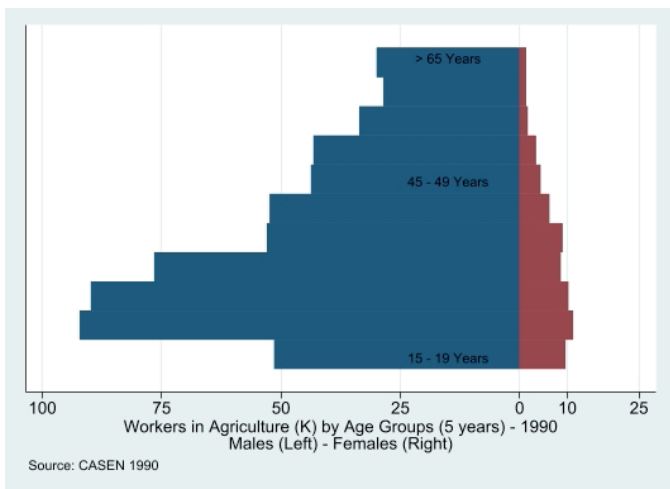

1990

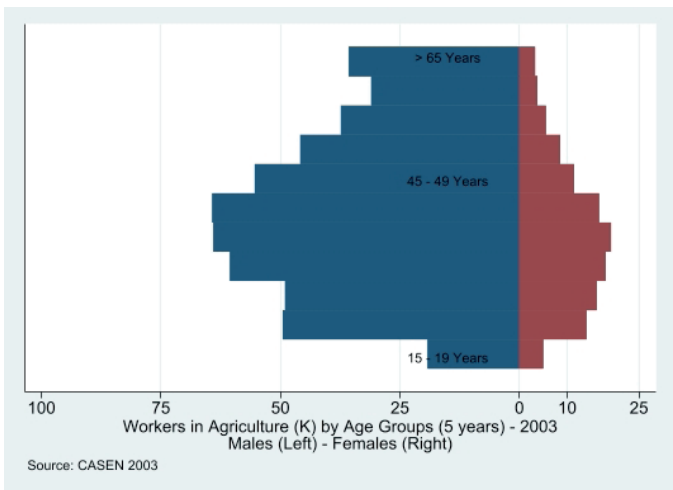

2003

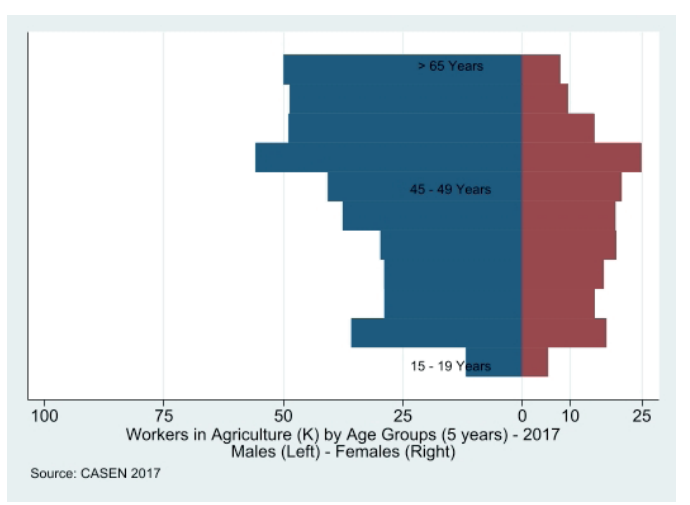

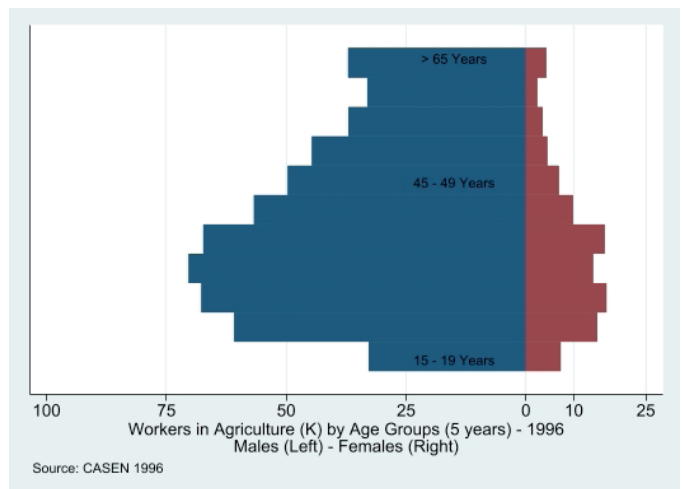

1996

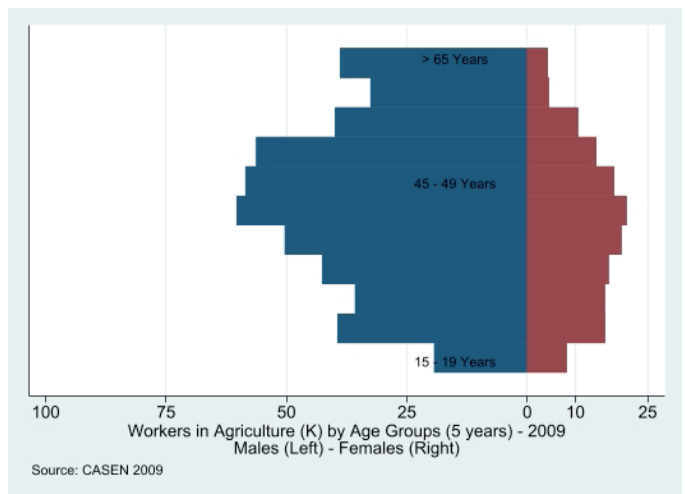

2009

\section{7}

Figure 4. Evolution of Age and Gender Composition of Agricultural Labor Force.Source: CASEN household surveys from various years.

where $L_{i}$ is the product of the total area devoted to the crop and $A_{i}$ is the average (technical) work requirements per hectare. That is, keeping the total agricultural area unchanged $\left(\Sigma_{i} H_{i}\right)$, the demand for employment in agriculture may increase if relative land uses change to crops with higher employment requirements. On the other hand, if the agricultural area increases, keeping the distribution of land use constant, the demand for employment will increase. However, it is possible to increase the agricultural area and at the same time reduce the demand for employment if there 
is a change in land use toward crops with lower employment requirements. However, one expects that there is a constant change in employment requirements over time $A_{i}(t)$. As employment becomes relatively more expensive, the use of capital increases, reducing labor requirements per hectare. Likewise, there are technological innovations that can help increase employment productivity, reducing these requirements. For example, the way fruit trees are aligned and pruned can make harvesting easier, labor more productive, and labor requirements fall.

In Chile, since the agricultural boom began after the debt crisis in the mid-1980s, the growth of the sector has been based on increasing the area with export-oriented crops that generate much more value per hectare but that at the same time have higher labor requirements. This trend of growth of high-value crops and high demand for employment continues to this day, as we shall illustrate. Figure 5 shows how agricultural land use has changed between the last two agricultural censuses using broad categories. The figure shows that annual crops (wheat, corn, etc.) and forage crops have fallen in relative importance, while the relative area of fruit trees and vegetables has grown, both of which have higher labor requirements than the former. The last census is almost a decade old, but by inspecting the annual fruit registries (Catástos Frutícolas), we know that this trend has not changed, with fruit-producing areas expanding in all main agricultural regions of Chile. This trend is expected to continue; that is, agriculture will continue to grow through the growth of the value of what is produced, increasing the area used by export-oriented crops (fruit trees), especially toward the south, where there is more room for growth. These production trends predict an increase in the demand for agricultural employment, both due to increases in agricultural area and due to the relative expansion of fruit trees, which have higher labor requirements than their traditional alternatives.

Despite this growing demand for labor promoted by the relative growth of labor-intensive crops, (Anríquez et al., 2016) show that there also have been important reductions in labor requirements brought about by technical change. The study shows that labor requirements fall at an average of $7 \%$ per year due to changes in technology. The study ultimately predicts an increase in the demand for labor as a result of this transition from agriculture
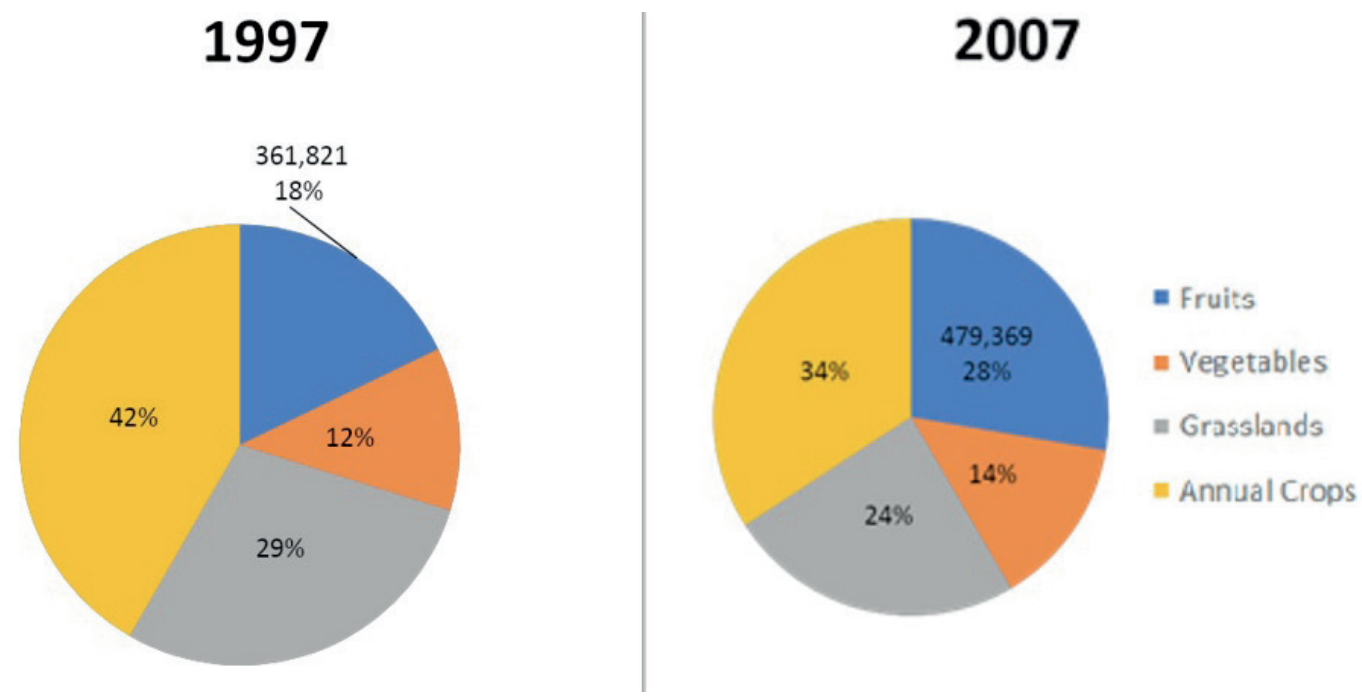

Figure 5. Evolution of Land Use between the Agricultural Censuses of 1997 and 2007.

Source: Agricultural and Forestry Census, 1997 and 2007, INE. 
to higher-value crops. This increase, however, is dampened by changes in production technology that allow reductions in technical labor requirements. Two important caveats to these predictions of increasing labor demand must be included in the analysis. First, there is evidence, still anecdotal until the new agricultural census is released, that important amounts of agricultural land are being lost to urban development in the forms of city growth or country houses. If these developments are large, predictions of employment demand growth should be diminished. The second important trend not considered in these predictions is the effect of climate change on land use. The net effect of climate trends on employment demand is harder to assess ex ante because the predicted drop in precipitation will promote the abandonment of swaths of agricultural land but also would add new agricultural land in the south converted to high-value/high-labor demand agricultural crops.

The supply of agricultural employment, on the other hand, depends mainly on the demographic characteristics of the population, including education levels, and on employment alternatives that can increase the opportunity cost of potential agricultural employees and promote their migration to other sectors. The authors show that men are more likely to be agricultural employees. On the other hand, in correspondence with international evidence (Hertz et al., 2009), education is negatively correlated with the probability of employment in agriculture (the result of returns to education being higher in other sectors). Access to infrastructure, also consistent with international evidence, reduces the probability of being employed in agriculture. The analysis made it possible to differentiate the effect of age on employment in agriculture in general and among seasonal employees, showing that seasonal workers are the youngest among agricultural employees and predicting that the probability of being a seasonal worker is reduced after 34 years of age.

Based on these relationships, the authors use demographic and education projections to pre- dict that in five years, the supply of agricultural employment will fall by $5.8 \%$ for wage earners in general and $12 \%$ for seasonal workers. Regardless of the exact amount the agricultural employment supply is predicted to fall in the future, we can predict with sufficient confidence that with the continued development of the country and rural development, the following trends will continue: the increasing age of the rural population (a product of the continuous falls in fertility rates and increases in life expectancies), the growth of connectivity and rural infrastructure, and the increase in the average levels of urban and rural schooling. All of these expected trends will promote a reduction in the supply of employment in agriculture in the near future.

This increase in the demand for agricultural employment and reduction in the supply of agricultural employment amounts effectively to what we are calling in this document 'the growing tightness in the labor market'. This growing 'tightness', however, does not mean that there will be a lack of employees or that national production is at risk. In terms of labor market analysis, we have growing demand accompanied by falling supply. In this scenario, we can be sure that wages will be higher, but we cannot predict what will happen with the equilibrium level of employment; they may be lower or higher depending on the elasticities of supply and demand and the magnitude of their respective expansion and contraction. This is what can be projected into the future, but it also roughly describes what has happened in Chilean agriculture since the beginning of the export boom. As shown in Figure 1, there is no long-term trend toward more or less employment in agriculture, but there is evidence (we show some below) of significant increases in wages in the sector.

Producers will pay those higher wages only if employees manage to produce an equivalent additional value (marginal productivity). That is why the permanent challenge of the sector is to increase the marginal productivity of workers to pay those higher wages caused by the growing 
'tightness' in the sector's labor market. This increased productivity can be achieved in a number of ways and is what the next section covers.

\section{Producer Responses to Rising Employment Costs}

In the previous section, we showed the long-term trends that have driven up employment costs for farmers, which are the same trends that most likely will continue to push up labor costs in agriculture. Further below, we present evidence of relative rises in the incomes of wage earners in agriculture. In this section, we take as a fact that per output unit employment costs will continue to rise, and we review the menu of strategies that employers have at their disposal to deal with these increases.

One possible response of producers to the rise in labor costs is simply to reduce the use of employment, assuming the loss in yields that this implies. In vegetables and some fruit trees, it may be profitable to harvest more than once (a main harvest and a subsequent rake), but if labor costs increase too much, the producer may decide to harvest only once, accepting the lower yields. This strategy can be perfectly optimal, and the reader must consider that the final objective of producers is to maximize income. If the additional (marginal) benefit of that second harvesting effort is less than its employment costs, it should not be done.

Another option for the producer, perhaps the most used but not available in the short term, is to change the land use and change crops. A farmer ultimately cares about the income-to-cost ratio. If relative sales prices are relatively constant over time, farmers will eventually be forced to abandon crops with rising labor requirements. For example, national fruit registries show that although fruit acreage has been steadily increasing, table grape acreage has reduced its area by approximately $5 \%$ during this century. The reduction in the area with table grapes is due to many factors, including price expectations and increasing competition from other producers in the Southern Hemisphere, such as Peru. However, the fact that it is one of the crops with the highest seasonal employment requirements also helps to explain this drop. Likewise, among the fruit trees that have seen their planted surface grow at a faster rate during this century are walnut and hazelnut trees (12.3\% and $23.8 \%$ per year, respectively), compared to $3.2 \%$, which is the annual growth rate of the fruit trees area during the same period. There is no doubt that lower labor requirements (and in this case easier mechanization) are behind the remarkable expansion of these crops.

The response most commonly employed by producers, and the one that leads to the greatest misunderstandings, is mechanization. Mechanization, understood as the increasing use of machines at different stages of the production process in agriculture, is a permanent feature of the development of the sector. To discuss its implications for employment, one must separate it into two different types of mechanization: that which "assists" the labor force and that which "substitutes" labor.

A good example of mechanization that assists the workforce can be given by thinking about the harvesting process, which is the most laborintensive stage of fruit production. The traditional method of harvesting consists of harvesting the fruit using and moving ladders and then transporting the filled bins to a nearby tractor or collection center. The same task with mechanized assistance can be achieved by moving the pickers on mobile platforms of different heights, followed by a conveyor belt that facilitates the transport of the fruit boxes once filled. In some cases (Californian horticulture), final packing is done at the harvest field to reduce transportation and labor requirements. This type of mechanization has important consequences for workers. Increasing the productivity of workers allows for increasing their wages. However, a perhaps more important 
consequence is that the supply of work increases by partially reducing physical effort and allowing more women and older people to assist in these tasks (remember that seasonal workers are the youngest among agricultural employees).

The other type of mechanization, the one that replaces employment, also is another alternative to deal with increasing labor costs. However, when harvesting is the job being substituted by mechanization, the destination of the final product is generally changed as well, as mechanized harvesting does not achieve the same level of care as manual harvesting. After mechanized harvesting, fruits generally end up processed or frozen (IQF), where they reach a lower value. In the case of Chile, this incompatibility between mechanized harvesting and fresh sale is accentuated by the fact that the target markets for the fruits are export markets, with final destinations far from Chile. Therefore, delicate (and hence manual) harvesting is required for fruits to arrive in good condition at their final destinations. Although mechanization that substitutes employment can be applied in other stages of the fruit production process, it is the harvest that attracts the most attention because it is the process that accumulates the most labor costs. Not all fruits are suitable for a mechanized harvest given current technology. For example, in Florida, USA, where orange trees are harvested to process fruits into juices, almost all the fruit is harvested by hand, despite efforts and research to mechanize the work since the 1950s (Calvin \& Martin, 2010). In this case, the fear of damaging the plant inhibits the mass adoption of existing technologies. The harvesting technologies available are specific to the crop; therefore, they require constant research and innovation and are generally expensive, implying a significant fixed cost, which can lead to the consolidation of smaller-scale farms when a crop is mechanized.

When there is mechanization that substitutes labor, there are jobs that are lost: that is the final objective of this type of mechanization, to reduce the demand for employment. However, do not think that this process of the modernization of high-value agriculture threatens the well-being of the poorest population, those who are generally employed in these activities. First, the mechanization process has been a continuous process in export agriculture in Chile and has not prevented the sector from growing wages faster than other sectors (see evidence below). However, the demographic and country development trends described above predict quite clearly that the supply of labor in agriculture will continue to contract, while the agricultural sector will continue to expand. The permanent challenge of the sector is therefore to reduce its employment requirements, and this mechanization is one of the strategies that allows it. In the short term and during the valleys of macroeconomic cycles (when parts of the urban unemployed return to the countryside), this mechanization could mean lower employment and wages in the agricultural sector. However, in the medium and long term (the term in which research and development projects that promote mechanization mature), demographic and country growth forces dominate, reducing the supply of agricultural employment and preventing drops in wages, as has been happening continuously since the 1980s. Finally, the employees of more mechanized agriculture, although they are fewer, have more training, are more productive, and have access to higher wages.

The other strategy available to farmers to face rising labor costs is to increase the productivity of their workers, which is mainly achieved by improving and modernizing the administration of human resources. First, we must establish that Chilean workers do not reach their productive potential. This observation can be supported by observing the productivity gaps observed between California (with a comparable agricultural sector with respect to agroecology and product mix) and Chile. Table 1 shows the different technical requirements for labor and related costs to produce the same number of boxes of table grapes per hectare between California and Chile, as reported in (Rebolledso \& Melo, 2008). The bottom line is that in California, 
it takes almost a quarter of the man-hours required in Chile to produce the same amount of grapes already packed and ready for distribution. This appears as a fairly transparent labor productivity measure, but it is a misleading comparison. This is because as the authors emphasize, the Chilean grape is harvested to travel important distances, while the Californian grape is close to its final destination, which means that inherently the Chilean grape has higher labor requirements (more delicate handling), especially in harvesting and packing tasks. Additionally, workers in California may have access to greater mechanization that facilitates their productivity. However, there are other tasks, such as pruning, that are more comparable, and the gap is two to one between Chile and California in terms of labor productivity. Billikopf (2014) presents more evidence of this gap in productivity or differences in employment requirements. The author compares three Chilean fruit packings with one in California and measures the percentage of fruits ordered correctly by the packers. The study shows that in California packing, not only is the average of correct orderings per packer higher by approximately $85 \%$ vs. $75 \%$, but the variability of the packed fruit is also much lower in California. In conclusion, there is a real gap in the productivity of agricultural workers between California and Chile. This gap is attributable to access to different technologies, depends on the task, and varies over a wide range between $15 \%$ and $400 \%$.
Greater productivity in agricultural work can be achieved by improving human resource management, improving work-environment relationships, and making the sector follow the best practices of any other productive sector. It is beyond the scope of this document to go into the details of how to improve human resource management in all its facets. However, here, we want to highlight some aspects of human resource management (HRM) in the agricultural sector in Chile, which reveal a significant gap with respect to best practices in this area.

Perhaps one of the essential characteristics of agricultural work and one of the issues that has raised the most interest in the discipline of agricultural economics is the asymmetry of information in agricultural employment. Due to the inherently high supervision costs, the asymmetry of information between employers and employees regarding the level of effort deployed in agricultural work renders agricultural employment different from that of other productive tasks. Given the high supervision costs in agriculture, more than in other sectors, labor agreements that generate incentive compatibilities become especially important (see, for example, Bharadwaj, (2015); Feder, (1985)). In agriculture, contracts with incentive compatibility are outcome-based contracts, usually composed of a fixed payment plus a variable payment based on rows pruned,

Table 1. Labor Costs in Production of Table Grapes in 2006: Chile and California (adjusted to equivalences of boxes produced).

\begin{tabular}{lcccc}
\hline \multirow{2}{*}{ Labor } & \multicolumn{3}{c}{ Work days/ha } & \multicolumn{2}{c}{ US \$/ha } \\
\cline { 2 - 5 } Pruning & Chile & California & Chile & California \\
Leaf removal & 21 & 9 & 336 & 736 \\
Cluster arrangement & 37 & 5 & 592 & 416 \\
Harvest and Packaging & 60 & 10 & 960 & 800 \\
Other tasks & 140 & 50 & 2,240 & 4,000 \\
Total & 112 & 31 & 1,797 & 2,504 \\
Average cost/day & 370 & 105 & 5,925 & 8,456 \\
\hline
\end{tabular}

Note: Adapted from (Rebolledo \& Melo, 2008). 
kilos harvested, or another observable indicator of productivity. In the aforementioned study by (Anríquez et al., 2016), the authors showed that to the surprise of experts, more than half of the seasonal workers were hired with fixed pay per day salaries instead of incentive-compatible contracts. Consistent with what is expected (Cowling, 2001), the study showed that those with an incentive-compatible contract earned an average of US\$ $\$ 60$ more per month than day laborers (2013 data), everything else being constant (age, gender, education, etc.). Another example of the gap in HR management is the lack of training in jobs. Only $22 \%$ of seasonal employees receive training, when $90 \%$ of those who receive it consider it useful or very useful, according to the same survey. Furthermore, these are not just perceptions; an analysis of the determinants of income shows that those who receive training earn US\$40 more than their peers. The authors of this study also highlight that good personal treatment from farm leadership is highly valued by employees: up to \$US60 thousand per month. This is another sign of poor HR management. Although good personal treatment is justified from an ethical perspective, from an economic and management perspective, the absence of good personal treatment reflects problems of HR management and training among middle managers and supervisors, who normally deal with employees on a day-to-day basis. On the other hand, there are innumerable failures in the management of downtime in productive tasks, as highlighted by (Rebolledo \& Melo, 2008), that can be improved. Furthermore, there are simple changes that can increase productivity, such as bringing hygienic services closer to workers or reducing the distances that they carry their loads. The different evidence collected and presented here is hidden good news: although on average Chilean farms display significant flaws with respect to the best HR management practices, Chilean agricultural labor productivity has ample growing room.

\section{Off-farm Responses to the Increasing "Tightness" in the Agricultural Labor Market}

In the aforementioned survey of seasonal workers, presented in (Anríquez et al., 2016), there also are surprises related to the prevalence of intermediaries in the recruitment and hiring of employees in agriculture. According to the survey, only $8 \%$ of those interviewed discovered their last job either through a contractor or recruiter (enganchador, as called in Chile). On the other hand, approximately $70 \%$ of the agricultural employees in the survey were employed on just one farm during the previous agricultural season. These results are surprising because in a tight labor market, one of the ways to increase the effective supply is by making it easier for agricultural employees to provide their services on various farms during the season. Just as good HR management within the premises seeks to reduce downtime, at the market level, efficiency is increased when the downtime of temporary employers between jobs is reduced. In a tight labor market, there are opportunities to offer services to link labor suppliers with demand, and this is the role that intermediaries, contractors, and recruiters play. As a point of reference, one can see what happens in the US: in 1987, in Florida, $47 \%$ of employment expenditures were made through contractors, and in California, this percentage reached $30 \%$ in the same year (Polopolus \& Emerson, 1991). It is reasonable to expect these numbers to be even higher today.

Following the classification of Caro (2012), we can identify three types of intermediaries in the Chilean agricultural labor market:

1) Recruiter (Enganchador): They fulfill a paid function of recruiting workers for a task, while the worker is ultimately hired by another employer, the farmer. It is generally observed that the recruiter is a trusted seasonal worker who receives a bonus for this work. 
2) Contractor: He is usually a person, not an enterprise, and works in agriculture as an employer of labor. They provide services to the farmer under a contractual agreement, at their own risk, with workers as their dependents, i.e., subcontracting work.

3) Temporary services company (TSC): They arose from Chilean subcontracting law 20,123, in force since 2007. They appear as formal legal enterprises that provide temporary workers for specific services. The payment of salaries and social security obligations is the obligation and responsibility of the TSC.

In their study of agricultural employment recruitment, (Vargas \& Paillacar, 2000) classified agricultural firms into two types. Type 1 requires work of low frequency and duration and high seasonal incidence (e.g., fruit growing and horticulture). Type 2 companies are characterized by a high frequency and duration of work and a low seasonal incidence (e.g., production of poultry, pig meat and dairy). Companies in the first category use contractors most frequently.

The literature that has studied the phenomenon of contractors in agricultural labor markets has identified the main services provided by these intermediaries ${ }^{1}$ :

1. Coordinate the relationship between employer and worker.

2. Serve as the worker's voice in negotiations with employers, simplifying the process and allowing more professional relationships between both parties.

3. Disseminate information on local labor market conditions for workers and employers.
4. Assume the cost and risk of HR management, freeing the farmer from the costs associated with managing and supervising seasonal workers.

5. Help in the logistics of the workers, providing transportation, communication, and/or accommodation coordination.

6. Help with (assumes the risks associated with) administrative costs, such as carrying out legal procedures, payment of taxes, and others.

7. Serve workers by granting them short-term loans.

From the perspective of reducing frictions in the agricultural labor market, the first service, that of coordination, is the most important. By reducing frictions, we mean facilitating transactions, which in this market are job hirings. Lower friction benefits all parties (farmer, intermediary, and worker). Transferring the hiring risk from the employer to the contractor also is very important, as it helps eliminate the problem of incentive matching and costly supervision ${ }^{2}$. The contractor tends to know his workers better and has advantages from an HR management perspective. For example, a farmer can hire a crew through the contractor to carry out a harvest, and the technical parameters of the work can be established (e.g., remaining fruits on the plant, fruit damage at harvest, etc.). This type of agreement provides compatibility of incentives, because from now on it is the crew that assumes the cost of supervision: coworkers have the incentive to quickly finish the work to find other contracts, and to supervise among themselves so that there are no "free riders".

A frequent concern associated with increasing contractor use in the sector is related to a pos-

\footnotetext{
${ }^{1}$ See (Roumasset \& Lee, 2007; Roumasset \& Uy, 1980; Vandeman et al., 1991).

${ }^{2}$ Examples of the risks associated with hiring are the risk of the worker giving less effort (when supervision is costly and information asymmetric) and the risk of receiving a financial penalty for informal hiring (without a work contract or incomplete payment of social security).
} 
sible increase in informality in employment and even to a deterioration in working conditions and worker treatment. However, a contractor has better incentives than a seasonal employer to treat his employees properly. The contractor needs his workers for several harvests, not just one, during the season. Furthermore, for the same reason, the benefits of worker loyalty are greater for a contractor than for a seasonal employer. A different issue is the full payment of employment social security contributions, or the 'formalization' of work. Informality in the Chilean agricultural labor market is the result of the coinciding benefits of informal employment. Small farm employers have an incentive to underdeclare labor costs to simplify their tax returns. Workers have an incentive to declare less income to qualify for some public programs. The solution to this problem has to come from the state: on the one hand, eliminating the incentives to underdeclare income for agricultural workers who do not want to lose social benefits for earning high sums for just three months a year; and on the other hand, providing a regulatory framework that allows the development of these contractors accompanied by adequate supervision.

As the agricultural labor market continues to become "tighter", as predicted in this document, the prevalence of middlemen in transactions is expected to increase, as observed in California, for example. However, it is not only intermediaries who can help reduce friction in the labor market. Due to the nature of agricultural labor markets, in which transactions are carried out in the rural world, where the flow of people and information is more difficult than in cities, there are other agents who can help. There is the possibility that unions of agricultural workers will develop, and they also can collaborate in coordination. Likewise, public bodies, such as municipalities, can help by transmitting information and coordinating. What is clear is that there is much room to grow in this regard as well, when approximately three in four agricultural employees worked for only one employer during the peak employment season.

\section{Evolution of Agricultural Wage Earners Income}

The evolution of agricultural labor markets that we have outlined thus far describes an increasingly tight market in which wages should rise rapidly because the resource that is increasingly relatively scarce is the workforce. A supply that is reduced over time, and a growing demand for labor from agriculture that specializes in sectors of higher value but that also is labor intensive, can only be consistent with significant increases in wages and productivity. In this section, we review whether these predictions can be confirmed with the available evidence.

First, we conduct an inspection of the relative income between construction and agriculture workers. As argued above, this comparison is relevant since in an integrated economy such as Chile's, both sectors compete for the same human resource: unskilled labor. Figure 6 shows the evolution of relative wages for short-term (seasonal) employees in agriculture and construction. The indicator in this case is the relative wages for short-term employees in agriculture relative to their peers in construction. The figure shows that although there was a drop between 2009 and 2015, there was a long-term upward trend between 2000 and 2017. In other words, the gap between salaries for temporary employees in agriculture compared to construction salaries has been closing.

This trend provides signs of the significant increase in wages in agriculture; however, it does not tell the whole story of the evolution of agricultural wages, since these relative wages depend to a great extent on sectoral performance. Therefore, another perspective on the evolution of agricultural salaries can be attained by comparing its evolution to the trend of income of other workers in agriculture, namely, self-employed workers in agriculture and commercial farmers, who are agricultural employers. Employers, for example, receive returns (payments) not only for their work but also for the land they own, the capital they employ in agricultural operations, and their managerial services. To analyze relative income growth, we propose the following decomposition of per capita income. 


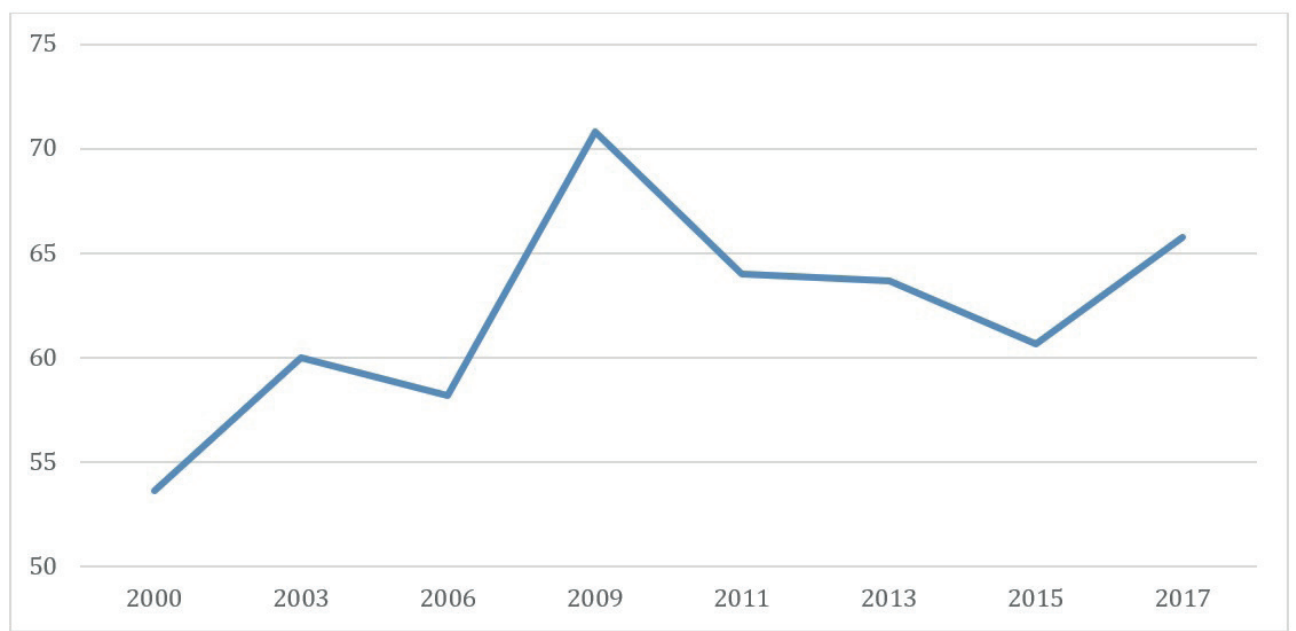

Figure 6. Income of Nonpermanent Workers in Agriculture as a Percentage of Income of Nonpermanent Workers in Construction

Source: Author's estimate using data from the CASEN survey.

The growth of per capita income can be decomposed into groups $(j)$ according to the following formula:

$$
\frac{\Delta \overline{\mathrm{y}}_{t}}{\overline{\mathrm{y}}_{t-1}}=\sum_{j} s_{t-1}^{j} \frac{\Delta\left(\alpha_{t}^{j} \overline{\mathrm{y}}_{t}^{j}\right)}{\alpha_{t-1}^{j} \overline{\mathrm{y}}_{t-1}^{j}}=\sum_{j} s_{t-1}^{j}\left(\frac{\Delta \alpha_{t}^{j}}{\alpha_{t-1}^{j}} \frac{\Delta \overline{\mathrm{y}}_{t}^{j}}{\overline{\mathrm{y}}_{t}^{j}}+\frac{\Delta \alpha_{t}^{j} \overline{\mathrm{y}}_{t}^{j}}{\alpha_{t-1}^{j} \overline{\mathrm{y}}_{t-1}^{j}}\right)
$$

The mathematical details of deriving this formula can be inspected in (Valdés et al., 2010); here, we intuitively explain its meaning. The formula is an exact equality that indicates that the growth of mean per capita income $(\bar{y})$ between $t$ and $(t$ $-1)$ is equal to the sum of the growth of the per capita income of each group $(j)$ weighted by the relative size of each group $s_{t-1}^{j}$. The relative size of each group $S_{t-1}^{j}$ is equal to the relative size in terms of the population of each group $\alpha_{t}^{j} \equiv \frac{N_{t}^{j}}{N_{t}}$ (where $N_{t}^{j}$ is the population that belongs to group $j$, and $N_{t}$ is the total population) scaled by the

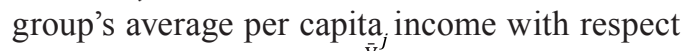
to the total mean income $\frac{\bar{y}_{t-1}^{j}}{\bar{y}_{t-1}}$. On the other hand, the average growth of each group $j, \frac{\Delta\left(\alpha_{t}^{j} \bar{y}_{t}^{\prime}\right)}{\alpha_{t-1}^{t} \bar{y}_{t-1}^{\prime}}$, can be decomposed into growth of the group's per capita income, $\frac{\Delta \dot{y}_{t}^{j}}{\bar{y}_{t}^{j}}$, the relative growth of the group $\frac{\Delta \alpha_{t}^{j}}{\alpha_{t-1}^{j}}$ in terms of population, and a residual, $\frac{\Delta \alpha_{t}^{j} \Delta \bar{y}_{t}^{j}}{\alpha_{t-1}^{j} y_{t-1}^{j}}$ . This is a very useful per capita income growth decomposition, as it allows differentiating between the simple growth of per capita income of each group $\frac{\Delta \bar{y}_{t}^{j}}{\bar{y}_{t}^{t}}$ and their contributions to the growth of overall per capita income, which is mediated by its population weight $\alpha_{t}^{j}$ and the economic weight of each group, $\frac{\bar{y}_{t-1}^{j}}{\bar{y}_{t-1}}$.

In this exercise, we concentrate the analysis on the per capita income of households that receive agricultural income. Furthermore, the households that receive agricultural income are divided into three excluding groups, according to their main source of agricultural income:

- Self-employed in agriculture that are employers (Employers)

- Self-employed in agriculture (Self-employed), and

- Salaried agricultural workers (Wage workers). 
The second group, the self-employed, includes mainly what we call subsistence farming, since if a family farm is prosperous enough, it is an employer. A similar effort is presented in (Pérez et al., 2020) but extended to employment by gender and temporary vs. permanent wage employment. Tables 2 to 4 contain the results of this exercise, dividing the changes in income into three broad periods: between 1990 and 1998, between 1998 and 2009, and between 2009 and 2017. Column 1 of these tables shows us the population weights of these three groups. The groups are weighted by the total population that they represent, not only the employees but also the household members they represent. Through the three tables, it can be seen that both the groups of employers and self-employed workers have been relatively shrinking, which implies that the third group, that of wage earners, represents a growing share of the population. The fourth column describes the per capita income growth of the three groups. The tables consistently show that wage earners have seen their average earnings grow at a much higher rate than that of employers and faster than that of self-employed individuals in two of the three periods. The last column concludes the final contribution of each group to the average per capita income growth of those who depend on agriculture. Due to their higher growth rates and their larger relative size, wage earners account for almost all the growth in household income linked to agriculture. This ultimately means that the economic well-being of the households of agricultural wage earners has grown proportionally much faster than that of employers and the self-employed in agriculture ${ }^{3}$, closing the relative income gap between wage earners and the other two groups.

Table 2. Agricultural Household Income Growth (1990-19

\begin{tabular}{|c|c|c|c|c|c|c|c|}
\hline \multirow{5}{*}{ Group } & \multicolumn{2}{|c|}{$\begin{array}{l}\text { Group Size } \\
\text { Group }\end{array}$} & \multicolumn{3}{|c|}{ Contribution to Growth } & $\begin{array}{l}\text { Group } \\
\text { Growth } \\
\text { Group }\end{array}$ & $\begin{array}{l}\text { Total } \\
\text { Contribution to } \\
\text { Growth }\end{array}$ \\
\hline & \multirow{2}{*}{ (1) } & \multirow{2}{*}{ (2) } & \multirow{2}{*}{ (3) } & \multirow{2}{*}{ (4) } & \multirow{2}{*}{ (5) } & (6) & (7) \\
\hline & & & & & & $(3)+(4)+(5)$ & $(2) \times(6)$ \\
\hline & & & Composition & Income & & & \\
\hline & $\alpha_{t-1}^{j}$ & $s_{t-1}^{j}$ & $\begin{array}{c}\text { Change } \\
\Delta \alpha_{t}^{j} / \alpha_{t-1}^{j}\end{array}$ & $\begin{array}{c}\text { Growth } \\
\Delta \bar{y}_{t}^{j} / \bar{y}_{t-1}^{j}\end{array}$ & Residual & & \\
\hline Employers & 0.036 & 0.138 & -0.116 & -0.095 & 0.011 & -0.200 & -0.028 \\
\hline Self-Employed & 0.285 & 0.299 & -0.085 & 0.120 & -0.010 & 0.024 & 0.007 \\
\hline Agricultural Workers & 0.679 & 0.563 & 0.042 & 0.221 & 0.009 & 0.273 & 0.153 \\
\hline Growth of Income per Capita & & & & & & & 0.133 \\
\hline Average Annual Growth & & & & & & & 0.0157 \\
\hline
\end{tabular}

Source: Author's calculations using CASEN surveys.

\footnotetext{
${ }^{3}$ These results ratify and extend in time the qualitative results already reported in (Valdés et al., 2010).
} 
Table 3. Agricultural Household Income Growth (1998-2009)

\begin{tabular}{|c|c|c|c|c|c|c|c|}
\hline \multirow{5}{*}{ Group } & \multicolumn{2}{|c|}{ Group Size Group } & \multicolumn{3}{|c|}{ Contribution to Growth } & \multirow{3}{*}{$\begin{array}{c}\text { Group } \\
\text { Growth } \\
\text { Group }\end{array}$} & \multirow{2}{*}{$\begin{array}{c}\begin{array}{c}\text { Total } \\
\text { Contribution } \\
\text { to Growth }\end{array} \\
\text { (7) }\end{array}$} \\
\hline & & & & & & & \\
\hline & (1) & (2) & (3) & (4) & (5) & & $(2) \times(6)$ \\
\hline & & & Composition & Income & & & \\
\hline & $\alpha_{t-1}^{j}$ & $s_{t-1}^{j}$ & $\begin{array}{c}\text { Change } \\
\Delta \alpha_{t}^{j} / \alpha_{t-1}^{j}\end{array}$ & $\begin{array}{c}\text { Growth } \\
\Delta \bar{y}_{t}^{j} / \bar{y}_{t-1}^{j}\end{array}$ & Residual & & \\
\hline Employers & 0.032 & 0.098 & -0.137 & -0.043 & 0.006 & -0.174 & -0.017 \\
\hline Self-Employed & 0.261 & 0.270 & -0.314 & 0.778 & -0.244 & 0.220 & 0.059 \\
\hline Agricultural Workers & 0.707 & 0.632 & 0.122 & 0.571 & 0.070 & 0.763 & 0.483 \\
\hline Growth of Income per Capita & & & & & & & 0.525 \\
\hline Average Annual Growth & & & & & & & 0.0391 \\
\hline
\end{tabular}

Source: Author's calculations using CASEN surveys.

Table 4. Agricultural Household Income Growth (2009-2017)

\begin{tabular}{|c|c|c|c|c|c|c|c|}
\hline \multirow{4}{*}{ Group } & \multicolumn{2}{|c|}{ Group Size Group } & \multicolumn{3}{|c|}{ Contribution to Growth } & \multirow{2}{*}{$\begin{array}{l}\text { Group Growth } \\
\text { Group } \\
(6) \\
(3)+(4)+(5)\end{array}$} & \multirow{2}{*}{$\begin{array}{c}\text { Total } \\
\text { Contribution } \\
\text { to Growth }\end{array}$} \\
\hline & (1) & (2) & (3) & (4) & (5) & & \\
\hline & & & Composition & Income & & & \\
\hline & $\alpha_{t-1}^{j}$ & $S_{t-1}^{j}$ & $\begin{array}{c}\text { Change } \\
\Delta \alpha_{t}^{j} / \alpha_{t-1}^{j}\end{array}$ & $\begin{array}{c}\text { Growth } \\
\Delta \overline{\mathrm{y}}_{t}^{j} / \overline{\mathrm{y}}_{t-1}^{j}\end{array}$ & Residual & & \\
\hline Employers & 0.027 & 0.053 & -0.510 & 0.159 & -0.081 & -0.432 & -0.023 \\
\hline Self-Employed & 0.179 & 0.216 & 0.098 & -0.126 & -0.012 & -0.040 & -0.009 \\
\hline Agricultural Workers & 0.793 & 0.731 & -0.049 & 0.353 & -0.017 & 0.286 & 0.209 \\
\hline Growth of Income per Capita & & & & & & & 0.178 \\
\hline Average Annual Growth & & & & & & & 0.0207 \\
\hline
\end{tabular}

Source: Author's calculations using CASEN surveys. 
The higher rate of growth of the per capita income of wage workers and the growth of its economic share $\left(s_{t}^{j}\right)$ are consistent with the trends described above: a steady increase in the demand for agricultural wage workers and a reduction in the labor supply that translates to rapid wage increases. On the other hand, the fast reduction in the size of employers suggests that land consolidation of farms may be occurring, particularly in exportoriented farming. This hypothesis, however, needs to be tested with new agricultural census data as it becomes available.

This important result can be contrasted with the national accounts, and they should paint a consistent story. The fact that wages are growing faster than employers' incomes means that the share of income generated in agriculture that goes into the wage bill must be growing. In the national accounts, the value added generated by the sector can be identified, which is equivalent to the gross value of agricultural production minus what the sector purchases as inputs from other sectors of the economy. These intersectoral transactions are recorded in the input-output matrix. The value added is equivalent to the income generated by the sector and is used to pay the owners of capital (including land), sector taxes if any, and work through wages. The results of household surveys should translate into a growing proportion of the value added in agriculture going to wages. This is confirmed in Table 5, where it shows that the proportion of agricultural value added assigned to wages grew consistently from $27 \%$ to $43 \%$ between 1986 and 2008, the last available national accounts base year. To highlight the sectoral differences, the table includes the evolution of the mining sector, which has shown the opposite trend, with a drop in wages as a proportion of value added from $29 \%$ to $12 \%$ in the same period. Finally, the construction sector that has been compared throughout this document does not show a constant trend, since it first rose from $45 \%$ to $65 \%$ in 2003 but then fell to $47 \%$ in 2008 , a level very comparable to the proportion of value added that is paid in wages in the agricultural sector. If agriculture does not specialize in products that are less labor intensive (for example, annual crops) or easily mechanized (for example, walnut and hazelnut trees), this trend of a higher share of wages in value added should continue along with the growth of the sector.

\section{Public Policy Challenges Related to the Agricultural Labor Market}

From a welfare economics perspective, public intervention in markets is justified only when there are market failures, such as information asymmetries, externalities (positive or negative impacts not mediated by the market) including poverty, or coordination problems. From this perspective, we review here some of the public policy challenges in light of the trends in the agricultural labor market described above.

\section{Mechanization and innovation}

With respect to mechanization, the country has the advantage that its agroecology is very similar to the agriculture of California, which has a more developed economy and is therefore more advanced

Table 5. Percentage of Value Added of the Sector Captured by Wages (Agriculture, Mining, and Construction)

\begin{tabular}{lcccccccccccc}
\hline & \multicolumn{3}{c}{1986} & \multicolumn{3}{c}{1996} & \multicolumn{3}{c}{2003} & & \multicolumn{3}{c}{2008} \\
& Ag. & Min. & Cons. & Ag. & Min. & Cons & Ag. & Min. & Cons. & Ag. & Min. & Cons. \\
\hline Before Tax & 26.6 & 29.0 & 45.6 & 40.7 & 28.8 & 51.7 & 38.5 & 18.8 & 65.1 & 43.1 & 12.4 & 47.4 \\
\multirow{2}{*}{ After Tax } & 27.5 & 29.2 & 48.5 & 41.9 & 28.9 & 52.5 & 39.6 & 18.9 & 66.5 & 44.4 & 12.4 & 48.1 \\
\hline
\end{tabular}


in the permanent process of mechanization. This means that Chile can import solutions developed in the Northern Hemisphere. On the other hand, the country also is innovating with mechanized solutions developed domestically, which are expected to continue to grow. First, public policy does not have to discourage this process of the modernization of agriculture as a (wrong) way to protect the poorest. We have shown how the poorest (agricultural wage earners) have benefited disproportionately more from this increasingly mechanized agricultural model, and there is no reason to think that this should change in the future. Given the Chilean economic reality and its capital-labor price relationship (which is approaching but still far from that of the Northern Hemisphere), there is room for the adaptation of technologies developed in the North.

If the state is going to participate directly in promoting R\&D in machinery and the adaptation of technologies, it has to do so with the medium-sized agriculture sector in mind. This sector does not have the scale to be able to make its own investments in R\&D in machinery and technification, but it is of great social importance: $50 \%$ of the employees in agriculture in the mobile quarter December-February 2016 were employed in properties that employ fewer than 10 workers (INE, 2016). As the benefits of modernization are adequately captured by the private sector, it is essential that any success in this area be disseminated and easily accessible to the entire medium-sized agriculture sector.

$R \& D$ in variety improvement requires time horizons that do not attract the private sector, and in most cases, the improvements it generates are public goods ${ }^{4}$, with benefits that cannot be captured by the private sector. For these reasons, in almost every country in the world, there is public research on genetic improvement, and there is ample evidence that these are well-spent public funds with high social returns; see, for example, (Hurley et al., 2014). Therefore, public intervention in this area must continue, but these public investments must be better targeted given the socioeconomic reality of the country, for example, by not only looking for varieties that improve yields but also developing varieties that improve yields and facilitate their harvest (such as dwarfing fruit trees), understanding perhaps that the second characteristic is the most economically relevant.

\section{Migration}

Migration policy reforms are probably the most politically contentious, but in a long-term outlook, it is necessary to think about policies that can be copied from countries that have already walked Chile's path of development. International migration is very costly for migrants in pecuniary and nonpecuniary terms. That is why migrants are generally young and make use of migration networks. Migration networks play a very important role in migratory flows and explain why migrants in Chile tend to stay in the city and less commonly reach the countryside. There is anecdotal evidence that in the northern regions of Chile, there is significant participation of international migrants in agricultural work (Sapag and Cerda, 2016). However, they represent a very minor fraction of total agricultural employment. The figures from the last CASEN 2017 indicate that foreigners in Chile represent $4 \%$ of the population and $4.3 \%$ of employees. In agriculture, on the other hand, $2.5 \%$ of employees are foreigners. There also is anecdotal evidence, yet to be studied formally, that there is a growing presence of foreigners in seasonal work as a result of a large increase in the migration of Venezuelans and especially Haitians over the last four years. Given current migration trends, it is very likely that foreigners will continue to increase in agriculture, but they will likely continue to be relatively less than in the

\footnotetext{
${ }^{4}$ This is not the case with hybrid seeds, where private companies invest generously in R\&D.
} 
rest of the workforce. However, immigrants still play a role in the agricultural labor market. To the extent that the supply of unskilled labor increases in urban areas, they indirectly push down wages in the countryside and reduce the incentives to migrate to the city in the countryside, marginally reducing the contractions of the rural labor supply.

Thinking of an eventual immigration reform and given that the pressure from the agricultural sector for more labor will increase over the years, it is a good idea to look at foreign experiences. In California and throughout the United States, just over half of the workforce are undocumented migrants (Calvin \& Martin, 2010). However, in Australia, New Zealand, and Canada, among others (Connell, 2010; Vosko, 2013), there are programs to recruit short-term migrants that have worked, successfully attracting migrants from abroad to the countryside, and promoting circular migration, which is important to benefit from job training and experience.

\section{Modernization of HR administration in the field}

This document argues that some of the most important gaps in the development of the agricultural sector are in the management of HR. The benefits of efficient HR management are private, and companies that fail conspicuously in this area will be wiped out by competition. However, it can be argued that there is a public role in this area. Just as agricultural techniques and practices spread with extension, in which the state plays an important role, there also is a reduced role for the public sector in improving human resource management in the Chilean countryside. For example, the state can certify training programs that help in this area or design general education campaigns on administration, transmitting universally applicable skills. The extension in these areas falls within what experts call a toll good: it is not a pure public good because the benefits are highly excludable, but there is low rivalry in its consumption. More ideas about the public role in extension of this type can be seen in (Umali $\&$ Schwatz, 1994). Furthermore, the need for the modernization of HR management also calls for a renewal of the curricula and skills taught in agricultural tertiary education.

\section{Reducing friction in the labor market}

In an increasingly "tight" market of increasing value and with evident information and coordination problems, the public sector plays an important role. First, the public sector can help with the dissemination of information directly. However, perhaps a more important question is how the public sector may inhibit the development of private solutions. This document discusses how the prevalence of intermediaries and contractors is much higher in California than in Chile and that in Chile, its prevalence is probably suboptimal, given that it is an agent who sells desirable services for workers and employers. It is very likely that Chilean law is working against the expansion of intermediaries. For example, joint liability (between contractor and employer) for the payment of workers' contributions is a policy that achieves the objective of minimizing the evasion of these contributions; however, it inhibits the transfer of this risk from the employer to the contractor. Thus, this intermediary, who plays a very important coordinating role in the market, becomes less desirable. It is necessary to think about legislation that discourages informality but that does not discourage the participation of formal intermediaries.

\section{Challenges imposed by increasing feminization}

This document illustrates the phenomenon of the feminization of work in agriculture and argues how this is a phenomenon that will increasingly characterize agricultural employment. The increasing feminization of employment should lead to rethinking labor legislation in general and in agriculture in particular. Female employment requires special considerations in terms of flexible 
hours and job facilities, such as nurseries. Although the employers who "need" these women workers have the incentive to provide these facilities, it is the role of the state to ensure that basic norms are complied with. Less evident, on the other hand, is that the technical education provided by the state must ensure that it is reaching women because we know that increasingly they will end up in the fields, and the obstacles (time, cultural, etc.) that keep them away from educational centers must be overcome. It also is important to consider that women represent, as we have shown, the majority of de facto seasonal workers, so it is necessary to think about how social security is delivered to this most vulnerable group that we know is disproportionately female. This is not a complete overview of the gender challenges posed by the increasing participation of women in agriculture but rather an invitation to think about a complex issue.

\section{Conclusions}

The growing 'tightness' in the agricultural labor market presents important challenges for the development of one of the most dynamic sectors of the Chilean economy and is of great importance for the well-being of a significant proportion of the country's most vulnerable population. Longterm predictions are made above regarding the evolution of the agricultural labor market. These long-term predictions are perhaps more reliable than those of the short term, since they do not depend on the evolution of economic cycles but on demographic and socioeconomic forces that will be maintained as long as the country continues its economic growth path. These predictions foretell a growing tightness in the agricultural labor market: increases in the demand for agricultural employment and reductions in the supply. Fortunately, industry players know these challenges and respond promptly to price signals from the market. It is enough to inspect the Chilean fruit registries to discover a sector that is in continuous adjustment to changing economic conditions, among which the cost of labor is one of the main drivers. This document nevertheless identifies quite a few areas where the response of producers and the market is not the most efficient. It is in these particular areas, i.e., coordination, information, and administration, among others, where the public sector can play an important role in helping to remove market frictions, either through its direct action, changing the institutional and incentive frameworks, or promoting public-private alliances.

\section{Resumen}

G. Anríquez. 2021. Tendencias a largo plazo y desafíos políticos en los mercados laborales agrícolas chilenos. Int. J. Agric. Nat. Resour. 210-232. Este documento identifica las principales tendencias de largo plazo en los mercados laborales agrícolas en Chile. El documento muestra los crecientes envejecimiento, feminización y estacionalidad de la fuerza laboral agrícola. Se realizan proyecciones de largo plazo sobre la evolución de la oferta y la demanda de mano de obra en función de las principales tendencias demográficas y económicas. Estas proyecciones sugieren la continuación de tendencias ya existentes de una oferta decreciente y una demanda creciente de mano de obra agrícola, impulsada principalmente por la sustitución de cultivos tradicionales por cultivos de exportación intensivos en mano de obra, pero de mayor valor. Por lo tanto, el documento predice una continuación de la tendencia de rápido aumento de los costos de empleo en la agricultura. El documento analiza los desafíos que estas tendencias imponen a los agricultores y a los diseñadores de políticas públicas para enfrentar el desafío de los costos laborales en rápida expansión mediante el aumento continuo de la productividad de la mano de obra agrícola.

Palabras clave: Chile, mercados de factores, trabajo agrícola. 


\section{References}

Anríquez, G., Foster, W.E., \& Valdés, A. (2005). Encadenamientos del sector agrícola y su rol como amortiguador. In Alberto Valdés \& W. Foster (Eds.), Externalidades de la Agricultura Chilena (pp. 139-156). Ediciones Universidad Católica de Chile.

Anríquez, G., Foster, W., Melo, O., Subercaseaux, J.P., \& Valdés, A. (2016). Evidencia y desafios para el empleo estacional en la fruticultura de Chile. FIA.

Bharadwaj, P. (2015). Fertility and rural labor market inefficiencies: Evidence from India. Journal of Development Economics, 115, 217-232. https:// doi.org/10.1016/j.jdeveco.2014.07.001

Billikopf, G. (2014). Labor Management in Agriculture: Cultivating Personnel Productivity. University of California.

Calvin, L., \& Martin, P. (2010). The U.S. Produce Industry and Labor Facing the Future in a Global Economy. USDA Economic Research Service. https://www.ers.usda.gov/webdocs/publications/44764/err-106.pdf?v=9104.1

Caro, P. (2012). El Caso de Chile. In F. Soto Baquero \& E. Klein (Eds.), Empleo y condiciones de trabajo de mujeres temporeras agrícolas. FAO.

Connell, J. (2010). From blackbirds to guestworkers in the south pacific. Plus ça change...? Economic and Labour Relations Review, 20(2). https://doi. org/10.1177/103530461002000208

Cowling, M. (2001). Fixed Wages or Productivity Pay: Evidence from 15 EU Countries. Small Business Economics, 16(3). https://doi. org/10.1023/A:1011106420779

Feder, G. (1985). The Relation between Farm Size and Farm Productivity: The Role of Family Labor, Supervision and Credit Constraints. Journal of Development Economics, 18(2-3), 297-313. https://doi.org/10.1016/0304-3878(85)90059-8

Hertz, T., Azzarri, C., Winters, P., Quiñones, E.J., \& Davis, B. (2009). Wage inequality in international perspective: Effects of location, sector, and gender. FAO.

Hurley, T.M., Rao, X., \& Pardey, P.G. (2014). Reexamining the reported rates of return to food and agricultural research and development. American Journal of Agricultural Economics, 96(5), 1492-1504. https://doi.org/10.1093/ajae/ aau047

INE (2021). National Employment Surveys. https:// www.ine.cl/estadisticas/sociales/mercado-laboral/ocupacion-y-desocupacion.

Jarvis, L.S., \& Vera-Toscano, E. (2004). Seasonal adjustment in a market for female agricultural workers. American Journal of Agricultural Economics, 86(1), 254-266. https://doi.org/10.1111/ j.0092-5853.2004.00576.x

Pérez, R., Foster, W., \& Valdés, A. (2020). Empleo y distribución de los ingresos de los trabajadores agrícolas en Chile 1998-2017. ODEPA.

Polopolus, L.C., \& Emerson, R.D. (1991). Entrepreneurship, sanctions, and labor contracting. Southern Journal of Agricultural Economics, 23(1), 1-12. https://doi.org/10.22004/ ag.econ. 30283

Rebolledo, S., \& Melo, O. (2008). Estudios de Productividad Laboral. Programa de Mejoramiento de la Productividad Laboral Frutícola. Chile: Convenio UC-Subsole.

Roumasset, J., \& Lee, S.-H. (2007). Chapter 52 Labor: Decisions, Contracts and Organization. Handbook of Agricultural Economics, 3, 2705-2740. https://doi.org/10.1016/S15740072(06)03052-0

Roumasset, J., \& Uy, M. (1980). Piece rates, time rates, and teams. Explaining patterns in the employment relation. Journal of Economic Behavior \& Organization, 1(4), 343-360. https://doi. org/10.1016/0167-2681(80)90011-6

Umali, D., \& Schwatz, L. (1994). Public and Private Agnricultural Extension. Beyond Traditional Frontiers. World Bank.

Valdés, A., Foster, W., Pérez, R., \& Rivera, R. (2010). Evolución y distribución del ingreso agrícola en América Latina: evidencia a partir de cuentas nacionales y encuestas de hogares. CEPAL.

Vandeman, A., Sadoulet, E., \& De Janvry, A. (1991). Labor contracting and a theory of contract choice in California agriculture. American Journal of Agricultural Economics, 73(3), 681-697. https:// doi.org/ 10.2307/1242820 
Vargas, G., \& Paillacar, R. (2000). Estrategias de Reclutamiento y Selección de Recursos Humanos en Empresas Agrícolas de la Zona Central de Chile. Revista Ciencia e Investigación Agraria, 27(3), 169-180.

Vosko, L. F. (2013). National sovereignty and transnational labour: the case of Mexican seasonal agricultural workers in British Columbia, Canada.
Industrial Relations Journal, 44(5-6), 514-532. https://doi.org/10.1111/irj.12033

Winters, P., De la O, A.P., Quiñones, E.J., Hertz, T., Davis, B., Zezza, A., Covarrubias, K., \& Stamoulis, K. (2008). Rural Wage Employment in Developing Countries. FAO. http://www.fao.org/ fileadmin/user_upload/riga/pdf/aj301e.pdf 